medRxiv preprint doi: https://doi.org/10.1101/2021.06.23.21259373; this version posted June 28, 2021. The copyright holder for this preprint (which was not certified by peer review) is the author/funder, who has granted medRxiv a license to display the preprint in perpetuity.

It is made available under a CC-BY-NC-ND 4.0 International license .

\title{
Age-dependent inequalities in HIV/STI burden and care receipt among men and transgender persons who have sex with men in Nairobi
}

Adrian D Smith DPhil ${ }^{1 \S}$, Elizabeth Fearon $\mathrm{PhD}^{2}$, Rhoda Kabuti $\mathrm{MSc}^{3}$, Erastus Irungu ${ }^{3}, \mathrm{Mary}$ Kungu ${ }^{3}$, Hellen Babu ${ }^{3}$, Chrispo Nyabuto ${ }^{3}$, Peter Muthoga ${ }^{3}$, Peter Weatherburn $\mathrm{MSc}^{4}$, Adam Bourne $\mathrm{PhD}^{5}$, Joshua Kimani MBChB ${ }^{3,6}$

1. Nuffield Department of Population Health, University of Oxford, Oxford, UK

2. Department of Global Health \& Development, London School of Hygiene \& Tropical Medicine, London, UK

3. Partners for Health and Development, P.O Box 3737-00506, Nairobi, Kenya

4. Sigma Research, Department of Public Health, Environments and Society, London School of Hygiene \& Tropical Medicine, London, UK

5. Australian Research Centre in Sex, Health \& Society, La Trobe University, Melbourne, Australia

6. Department of Community Health Sciences, University of Manitoba, Winnipeg, Canada

\begin{abstract}
Background

Gay, bisexual and other men who have sex with men (GBMSM) and transgender persons (TP) bear high burdens of HIV and other sexually transmitted infections (STIS) in sub-Saharan Africa, yet evidence of HIV care coverage for these groups is sparse from the region despite prevailing stigma and discrimination towards these groups.
\end{abstract}

\section{Methods}

618 GBMSM/TP were recruited in Nairobi between May to December 2017 using respondent-driven sampling. Participants reported recent sexual behaviour, HIV testing and care receipt, and symptoms of STIs. Participants tested for HIV using Kenyan testing algorithms and GeneXpert methods, syphilis, viral hepatitis and ano-genital gonorrhoea and chlamydia. We assessed associations with HIV status and detectable HIV viral load using multivariable robust Poisson regression models.

\section{Findings}

$26.4 \%(286 / 618)$ were HIV positive of whom $76.5 \%$ were status aware, $65.3 \%$ were on ART, and $47.4 \%$ were virally suppressed $(<50$ copies/ml). Participants $18-22$ years old were less likely to be status aware, be receiving ART or to have achieved viral suppression. Mean log viral load was 3.14 log higher in 18-22 year olds compared to older participants. Bacterial STIs were frequently detected at both urethral and rectal sites and a majority of infections at both sites were asymptomatic by selfreport (rectal $82.2 \%$, urethral 90.8\%).

\section{Interpretation}

Engagement in the HIV diagnosis and care cascade among GBMSM/TP in Kenya is markedly better than in most sub-Saharan African countries. However it falls short of achievements among the general population in the country and cascades achieved in GBMSM in high income settings. Young men and transgender persons who have sex with men are least well served by the current configuration of adult key population services, and programmes should identify and address the sexual, social and developmental needs of adolescent and young key populations 
medRxiv preprint doi: https://doi.org/10.1101/2021.06.23.21259373; this version posted June 28, 2021. The copyright holder for this preprint (which was not certified by peer review) is the author/funder, who has granted medRxiv a license to display the preprint in perpetuity.

It is made available under a CC-BY-NC-ND 4.0 International license .

\section{Background}

Gay, bisexual and other men who have sex with men (GBMSM) and transgender persons (TP) bear disproportionate burdens of HIV risk and HIV infection around the world ${ }^{1-3}$, including in generalised epidemic settings in sub-Saharan Africa ${ }^{4,5}$. Structural and cultural obstacles, including criminalisation, institutional homophobia and societal antipathy towards these groups continue to challenge efforts to provide equitable access to effective HIV prevention and treatment, particularly in sub-Saharan Africa ${ }^{6}$. International agencies highlight the harmful consequences of unequal access to prevention and treatment upon members of these populations and to efforts to curb national HIV epidemics ${ }^{7}$. Yet despite clear targets for increasing status awareness and anti-retroviral therapy (ART) uptake among key populations ${ }^{8}$, very few sub-Saharan African countries conduct surveillance to monitor the effectiveness and coverage of treatment programmes for these populations ${ }^{9,10}$.

Kenya has a declining generalised epidemic with an adult prevalence estimated at $4.9 \%$ in 2018 , comprehensive national prevention and treatment responses including oral pre-exposure prophylaxis (PrEP), post-exposure prophylaxis (PEP), voluntary male circumcision, test and treat, and broad availability of viral load testing to support HIV care ${ }^{11}$. The Kenya population - based HIV impact Assessment (KENPHIA) study demonstrated the progress toward achievement of UNAIDS 90-90-90 targets in a national survey of Kenya adults ${ }^{12}$ : in 2018, 79.5\% of adult PLWHA (15-49 yrs) were aware of their HIV status, of whom $90.6 \%$ were receiving ART, of whom $90.9 \%$ (or $72 \%$ of all PLWH) were virally suppressed ${ }^{12}$.

Kenya has 15 years of research describing HIV burden among men who have sex with men. In Nairobi, the most recent estimate of HIV prevalence (based on data collected in 2010) was $18.2 \%$ over three times the prevalence amongst the general population ${ }^{13}$. National AIDS control policies include strategic goals to enhance HIV prevention and treatment service response for GBMSM in line with the WHO recommended package of key population interventions ${ }^{14,15}$. This has enabled a mixed model of prevention and care delivery through non-governmental organisations, private providers and state clinics largely concentrated in major cities. Whilst some providers monitor care retention and outcomes among their clients, the population coverage and quality of HIV care for GBMSM/TP is unknown.

We aimed to estimate the prevalence of HIV and other sexually transmitted infections in a population representative sample of cisgender male and transgender persons who have sex with men living in Nairobi, describe the HIV care cascade and viral load among GBMSM and TP living with HIV, and assess correlations with prevalence of both HIV infection and detectable viraemia in this context.

\section{Methods}

Recruitment and sampling Respondent driven sampling was used to recruit 618 participants between May and December 2017 following established methods ${ }^{16}$. Seed participants were referred to the study by three community organisations who provide services to GBMSM communities in Nairobi (GALCK, ISHTAR and HOYMAS). Following formative qualitative research, ten seeds were chosen to optimise diversity in age, marital status, gender identity, socioeconomic status and district of residence within Nairobi County.

Each participant was issued two recruitment coupons and instructions on how to recruit further eligible participants from their social networks. Inclusion criteria were: possession of a valid study coupon; age 18 or over; male gender assignment at birth or current identification as a man; residence within $50 \mathrm{~km}$ of Nairobi, and consensual anal or oral sexual activity with a man in the 
previous twelve months. Coupons detailed the location and contact details for the study site but disclosed no information about the purpose of the study. Coupons were uniquely numbered to verify recruiter-recruit links and coupon legitimacy. The opportunity for coupon duplication was reduced by use of non-standard grade watermarked paper, date stamping and limited period of validity after issue. Participants were reimbursed 300 Kenya shillings ( USD \$3) for each recruit they referred to the study who subsequently participated.

Study procedures Coupon recipients who satisfied eligibility criteria underwent informed consent procedures with study staff. Recipients were ineligible if they reported coupon receipt from a stranger, coercion to attend or previous participation in the study. Unique identity was established using a commercially available digital fingerprint scanner.

Personal behaviour was collected via self-completed SurveyGizmo ${ }^{\mathrm{TM}}$ questionnaire implemented in English and Kiswahili on touch-screen tablets. The questionnaire covered multiple domains including demographic characteristics; sexual behaviour; alcohol and other substance use; knowledge of HIV transmission risks; use of existing HIV/STI prevention methods; recent anogenital symptoms suggestive of STI; experiences of sexuality-related stigma, discrimination or violence ${ }^{17,18}$. In addition, the questionnaire included pre-validated measures of alcohol use and dependence ${ }^{19}$. Social network size was elicited from a sequence of questions yielding the number of men who have sex with men, over the age of 18 living in Nairobi and met in person in the last two weeks.

Participants were offered HIV counselling and rapid testing following Kenyan HIV Testing Services (HTS) guidelines using two commercial rapid diagnostic kits (RDT: Determine Alere HIV $1 / 2$ and First Response HIV 1-2.0 $)^{20}$. Blood specimens were tested for syphilis (TPHA/RPR), hepatitis B surface antigen and hepatitis $C$ antibody (Mircrowell ELISA, Bios USA) and qualitative or quantitative HIV-1 PCR conditional on rapid test results (GeneXpert Qual or HIV-VL). Urine and rectal swabs were collected and tested for Neisseria gonorrhoea and Chlamydia trachomatis using PCR (GeneXpert CTNG).

HIV care continuum measures were based on CDC guidelines with a viral suppression threshold of $<50$ copies $/ \mathrm{ml}^{21}$. Self-reported HIV status awareness and use of anti-retroviral therapy ART were collected both by computer-assisted survey and as part of HTS. Measures of linkage to care within 6 months of diagnosis and retention in care over the past 12 months were only elicited in the survey.

Persons living with HIV/AIDS (PLWHA) not reporting receipt of care were referred to government services for initiation of anti-retroviral therapy. HIV negative participants were referred for preexposure prophylaxis PrEP eligibility assessment. Treatment for other STIs was provided free and according to national guidelines. Condoms and water-based lubricants were freely available in the study clinic as was information about sexual risk reduction and other GBMSM/TP-affirming local sexual health services. Participants were compensated 500 Kenya shillings ( USD \$5) for completing study procedures, as approved by the ethics review board.

Statistical methods RDS diagnostics including visualisation of recruitment chains, convergence and seed dependence, and statistical assessment of recruitment homophily were analysed using the $r d s$ library for $\mathrm{R}$ version $3.4 .0^{22,23}$. Crude and sample weighted estimates (RDS-II method and excluding seed $^{23}$ ) of the prevalence of sociodemographic and behavioural factors, lab-confirmed and selfreported STIs and HIV cascade measures (for PLWHA only) are presented in accordance with good practice $^{24}$. Given evidence of under-reporting of status awareness and ART use in HTS and surveys alone (see supplementary materials), a composite cascade was derived combining both sources and 
medRxiv preprint doi: https://doi.org/10.1101/2021.06.23.21259373; this version posted June 28, 2021. The copyright holder for this preprint (which was not certified by peer review) is the author/funder, who has granted medRxiv a license to display the preprint in perpetuity.

It is made available under a CC-BY-NC-ND 4.0 International license .

treating any report of HIV awareness or treatment receipt as a positive response. Age and partner count quintiles among PLWHA were coded and used throughout for consistency.

Associations with HIV prevalence in the entire sample, and prevalence of detectable HIV viraemia among PLWHA only, were assessed using robust Poisson regression with a non-clustered sandwich estimator ${ }^{25}$ for an unbiased estimate of the prevalence ratio ${ }^{26}$. Multivariable models were specified including sociodemographic (model 1) or full (model 2) covariates associated with outcome at $p<0.100$. Given the bimodal distribution of viral load among PLWHA, comparisons between quantitative VL measures were limited to non-parametric significance testing (Kruskall-Wallis test) and distribution visualisation (Epanechnikov kernels). Analyses of association were not sample weighted, given the known risk of bias in applying network weights to multivariate analyses ${ }^{27}$ and likely correlation of pertinent behavioural measures with social network degree. Less than $5 \%$ of covariate measures were missing and were included in models as dummy variables. Analyses were performed in Stata version 16.

This study was approved by the Kenya Medical Research Institute Scientific and Ethics Review Unit (KERMI/SERU/CGMR-C/CSC 044/3334), the University of Oxford, Oxford Tropical Research Ethics Committee (OxTREC 47-16) and London School of Hygiene \& Tropical Medicine Human Research Ethics Committee (REF: 14144). All participants provided separate written informed consent to the questionnaire, sample collection and sample storage, and were able to withdraw from any portion of the study.

\section{Results}

761 individuals presented to the study site with the intention of participation. 124 were ineligible due to fake or missing coupons, repeat attendance, intoxication or failure to meet inclusion criteria. Of the 637 individuals with confirmed eligibility, 29 declined participation during consent procedures. Of 608 recruits and 10 seeds completing informed consent, one participant declined blood testing and six declined rectal swabs. Four seeds accounted for $516(84.9 \%)$ recruits. Depth of recruitment ranged from 1 to 19 waves per seed (median 7) (Appendix 1).

Table 1 shows the characteristics of enrolled participants. Median age was 24 years (IQR 21-29) with $38.2 \%$ between the ages of $18-22$ years. Most participants reported having attended post-primary education, however a high proportion of participants reported being unemployed. A minority of participants reported a birthplace outside of Kenya, predominantly in neighbouring East African countries, in particular Uganda $(n=90)$. Three-quarters of participants self-identified as gay or homosexual, and $15.0 \%$ self-identified as non-cisgender (predominantly transfeminine or female). Only $35.3 \%(30.9-39.9 \%, 229 / 580)$ reported having been in contact with community-based organisations targeting GBMSM/TP during the previous year.

On average, participants reported 2.99 (2.01-3.97) male sexual partners in the past three months. Male partner counts were higher among the $44 \%$ of participants who reported selling sex to men in the past year (mean 4.2 vs 2.0 different partners in the last 3 months, Kruskall-Wallis $p<0.001$ ). $49.0 \%$ (44.5-53.6) reported receptive anal intercourse in the past three months, and $28.3 \%$ (23.131.2 ) reported at least one episode of condomless receptive anal intercourse over that time. A significant proportion of participants reported sex against their will. Over a quarter of participants reported female sexual partners over that period and participants were similarly likely to have sold sex to, or purchased sex from, females. Among HIV negative participants, 59.2\% (237/396 53.4$64.6 \%)$ reported HIV testing within the last 6 months and 4.4\% (25/430 2.7-7.0\%) reported current oral PrEP use. 
medRxiv preprint doi: https://doi.org/10.1101/2021.06.23.21259373; this version posted June 28, 2021. The copyright holder for this preprint (which was not certified by peer review) is the author/funder, who has granted medRxiv a license to display the preprint in perpetuity.

It is made available under a CC-BY-NC-ND 4.0 International license .

186 participants tested HIV positive (crude $30.1 \%$, RDS-II 26.4\%). Two individuals were positive only on PCR testing, representing $2.1 \%(2 / 186,0.5-8.2 \%)$ of PLWHA or $0.76 \%(2 / 426,0.18-0.30 \%)$ of participants testing negative by the national RDT algorithm. Five participants had evidence of active syphilis infection, and hepatitis B and C prevalence was low. Laboratory confirmed rectal STIs were more prevalent than urethral STIs, and rectal GC was the most common site-specific STI. $82.2 \%$ confirmed rectal infections (90/106, 72.0-89.3\%) and $82.3 \%$ confirmed urethral infections $(49 / 60$, 68.8-90.8) were asymptomatic on self-report.

Table 2 shows crude and adjusted variable associations with HIV status. Across models, increasing age was strongly associated with increasing HIV prevalence. In fully adjusted models HIV prevalence rose on average $6.4 \%$ per year of age (5.0-7.9\%) $p<0.001$ ), from $13 \%$ among $18-22$ year olds to $48.9 \%$ among those over 32 years of age. Participants reporting a birthplace outside Kenya but within Africa had less than half the HIV prevalence of Kenyan-born participants in all models. Transfeminine participants had a 50\% higher prevalence than cisgender GBMSM after adjustment for sociodemographic factors, yet not after adjustment for behavioural factors. In crude analyses, HIV infection was associated with higher male partner counts, selling sex to men, and receptive anal intercourse. However, after adjustment, only reporting of recent receptive anal intercourse remained independently associated with HIV infection.

Figure 1a shows the composite, RDS-II adjusted care cascade among participants with HIV infection (see Appendix 2 for cascades based on survey and HTS measures only). 97.9\% (91.8-99.5\%, RDS-II, $\mathrm{n}=184)$ were detected by the HTS regimen, $76.5 \%(68.2-83.3 \%$, RDS-II, $n=137))$ reported status awareness and $65.3 \%(56.6-73.2 \%$, RDS-II, $n=129)$ reported currently receiving anti-retroviral therapy. $47.4 \%$ (38.9-56.0\%), RDS-II, $n=92$ ) of PLWHA were virally supressed ( $<50$ copies $/ \mathrm{ml}$ ). Median viral load was highest among two PCR positive participants with negative rapid tests $\left(6.46 \log _{10}\right.$ copies/ml), and declined significantly by each progressive step across the care continuum (Figure 1b). Among 131 participants declaring receipt of HIV care, 61 (41.7 (31.9-52.2\%) last received care in a community organisation, 44 (36.9\% (27.4-47.6\%) in a public hospital, and 26 (21.5\% (14.1-31.3\%) from a private provider.

Factors associated with detectable viraemia among PLHWA are reported in Table 3. A strong and significant inverse trend was apparent between increasing age and prevalence of detectable viraemia in both crude and adjusted models. On average, the prevalence of detectable HIV viraemia decreased by $4.2 \%$ per year of age $(1.8-6.6 \%$, test for linear trend $p=0.0001)$. These trends were apparent across all metrics of the HIV care cascade (Figure 2a). Median log viral load among participants aged $18-22$ was significantly higher than older age groups (4.44 vs $1.30 \log _{10}$ copies $/ \mathrm{ml}$, Kruskall-Wallis $p=0.0012$, figure $2 \mathrm{~b}$ ), and both participants with acute HIV infections were within this youngest age-group. Increasing levels of education attendance were also associated with a declining level of viral detection among PLWHA, however this trend was not statistically significant. Correlates of prevalent HIV viraemia in the demographically adjusted model (model 1 ) were payment for sex in the last three months (with either male or female partners) and recent condomless anal intercourse with female partners, whilst there was an inverse association with recently selling sex to male partners.

\section{Discussion}

Over a quarter of GBMSM and TP in Nairobi now live with HIV infection. These estimates are higher than previous estimates from the same city $\left(18.2 \%{ }^{13}\right)$ and compared to convenience samples elsewhere in Kenya $\left(19.8 \%\right.$ Malindi $2010^{28} ; 16.6 \%$ Kisumu $2015^{29}$ ). Extrapolation of the observed proportion with evidence of acute/early HIV infection not detectable by $4^{\text {th }}$ generation testing 
(estimated 14 day window period) suggests an annual HIV incident risk of $15 \%$ (4-58\%). Persistently high HIV/STI risk among is consistent with high reported behavioural and biological acquisition risks that have not improved over time ${ }^{13}$ : over $40 \%$ of GBMSM/TP report recent condomless anal intercourse and transactional partnerships, and a high proportion have co-occurring and asymptomatic STIs. Anti-retroviral prevention uptake remains poor and whilst the national PrEP programme was in the process of deployment during this study, subsequent evaluation since confirms inadequate uptake and persistence among GBMSM ${ }^{30}$.

However, this study does highlight significant progress in reaching key populations with HIV testing and care. We estimate that three-quarters of GBMSM/TP living with HIV in Nairobi are aware of their status and nearly half have been supported to achieve viral suppression, analogous to 77-85-73 against UNAIDS targets. This cascade compares favourably to GMSMS/TP cascades data elsewhere in sub-Saharan Africa $\left(18-53-76^{9}\right)$ as well as to that reported in global self-reported surveys (NA-82$58)^{31}$. This is by no means a small achievement of HIV programming within a societal context of homophobic discrimination and criminalisation of same sex behaviour ${ }^{6}$ and represents marked improvements in access to HIV care that will directly translate into better health outcomes for GBMSM and TP living with HIV. However, cascades fall behind those for PLWH in the Kenyan general population (80-96-91 in 2017) $)^{12}$ and for GBMSM and transgender in high income settings ${ }^{32}$.

Inequalities in coverage of HIV diagnosis and care were principally driven by age. We observed strong positive associations between increasing age and virological suppression, as well as other metrics of the care cascade. Median viral load was 3.14 log higher among participants age 18-22 living with HIV than older GMSM/TP (4.44 $\vee 1.30$ respectively, $p=0.0022)$, reflecting both lower status awareness and care engagement in addition to higher HIV incident risk in the youngest age group. The observation that HIV prevalence was $13 \%$ among $18-22$ year old GBMSM/TP suggests that risk begins earlier in adolescence when prevention and care may be even less accessible. Although comparable evidence is scarce from elsewhere in sub Saharan Africa, Ramadhani reports higher HIV risk behaviour and incidence, yet lower healthcare engagement, status awareness and virological suppression among $16-19$ year old Nigerian GBMSM/TP ${ }^{33}$

The WHO highlight the need for national responses to be acceptable to young key populations ${ }^{34}$, and our findings suggest a focus on GBMSM/TP youth is not only overdue but will be essential to the overall success of Kenyan key population HIV response. Improving accessibility to youth may require redress of structural barriers to service access, such as age-based consent criteria, training of staff to recognise additional needs of young MSM, but must also account for the prospect that young MSM will be sceptical of confidentiality and safety of healthcare settings ${ }^{35}$. Pettifor proposes that services for adolescent and young MSM need to be targeted and holistic, given the complex and concurrent challenges of conceptualising HIV risk and prevention during a period of personal biological and psychological change, and often alongside stressors related to acceptance and disclosure of sexual or gender identity to family and friends ${ }^{35}$.

Our findings also suggest that improved diagnostics could complement both HIV prevention and care for GBMSM/TP in Nairobi. A small but significant proportion of GBMSM/TP were identified with prevalent acute/early HIV infection accompanied by high viral loads, and undetected by current national testing practices. In addition we found a high proportion of GBMSM/TP with asymptomatic, urethral and rectal STIs, well recognised as a co-factor in HIV transmission ${ }^{36}$. Laboratory capacity for STI diagnosis remains limited and expensive in Kenya, therefore most providers, especially community-based organisations, rely solely upon syndromic management. Our findings concur with others in suggesting such approaches alone have unacceptably poor diagnostic performance ${ }^{37,38}$. The 
medRxiv preprint doi: https://doi.org/10.1101/2021.06.23.21259373; this version posted June 28, 2021. The copyright holder for this preprint (which was not certified by peer review) is the author/funder, who has granted medRxiv a license to display the preprint in perpetuity.

It is made available under a CC-BY-NC-ND 4.0 International license .

decreasing complexity and cost of point-of-care PCR technologies should encourage policy makers to re-evaluate the cost effectiveness of providing access to PCR-based HIV and STI diagnostics particularly in community settings ${ }^{39}$.

A key strength of the study was the population representative design which avoided many of the biases intrinsic to studies conducted solely among GBMSM/TP already engaged with service providers. RDS diagnostics suggest convergence on all main demographic measures, and these compared closely to a previous study of the same design in Nairobi ${ }^{13}$. Limitations of the study include the cross-sectional design (precluding examination of causal direction of correlates) and the reliance on self-reported measures of behaviours and service uptake that are potentially subject to memory error and social desirability bias. Foremost among these was differential under-reporting of status awareness and anti-retroviral use in surveys and with care providers. This phenomenon has been reported by a few other population-based studies and has the potential to significantly distort interpretation of cascade measures ${ }^{40,41}$ and underscores the need for verification of self-reported measures wherever possible.

In summary, coverage of HIV care for GBMSM and transgender persons living with HIV in Nairobi is close to that achieved in the general population and reflects the inclusive approach of the national HIV/AIDS strategy in Kenya. However, ending AIDS for key populations demands even better access to care, a re-energised PrEP response, and relevant HIV and STI diagnostics available wherever GBMSM/TP feel safe seeking these services. Going forward policy makers must now seek to understand and address the sexual health service preferences of adolescent and younger key populations in order to address existing inequalities in access to diagnosis and care services.

\section{Acknowledgements}

We would like to acknowledge and thank the commitment of study participants, and are grateful to our community partner organisations: the Gay and Lesbian Coalition of Kenya (GALCK); Ishtar MSM and Health Options for Young Men with AIDS (HOYMAS) for their support of study procedures and in dissemination of findings. We thank our administrative, counselling, clinical and laboratory staff at the TRANSFORM clinic and Partners for Health and Development for Africa (PHDA) for their hard work and dedication.

This study was funded by Evidence for HIV Prevention in Southern Africa (EHPSA), a UK aid programme managed by Mott MacDonald (award reference MM/EHPSA/WHC/0116029). The funder of the study had no role in study design, data collection, data analysis, data interpretation of writing of the report.

\section{Conflicts of Interest}

No author has conflicts of interest to declare.

\section{Author contributions}

ADS contributed to designing the study and data collection instruments, carried out quantitative analyses and wrote the first draft of the manuscript; $A B$ contributed to conceiving and designing the study and data collection instruments and drafting of the manuscript; JK and RK contributed to designing the study and data collection instruments, implementation of study procedures, and commented on the manuscript. El, MK, PM, HB and $\mathrm{CN}$ contributed to the implementation and 
medRxiv preprint doi: https://doi.org/10.1101/2021.06.23.21259373; this version posted June 28, 2021. The copyright holder for this preprint (which was not certified by peer review) is the author/funder, who has granted medRxiv a license to display the preprint in perpetuity.

It is made available under a CC-BY-NC-ND 4.0 International license.

operation of study procedures. PW and EF contributed to conceiving and designing the study and data collection instruments and commented on the manuscript. All authors approved the final draft.

\section{Data sharing}

Data from this study has not been deposited publicly because of the potential risk of deductive disclosure that may arise from individual data needed for valid analysis of the data, and the potential individual and social harms that may arise from such disclosure in a context of criminalisation and stigmatisation. However all authors aim to make the data underlying the findings of the study available for legitimate research purposes, and requests will be considered by the London School of Hygiene and Tropical Medicine Research Operations Office Data Management lead (alex.hollander@lshtm.ac.uk). The request must specify the purpose of research, the list of required variables, and if personally identifiers or sensitive data are sought, specify measures to maintain information security and governance that will be applied in storage, handling and reporting the data. 
medRxiv preprint doi: https://doi.org/10.1101/2021.06.23.21259373; this version posted June 28, 2021. The copyright holder for this preprint (which was not certified by peer review) is the author/funder, who has granted medRxiv a license to display the preprint in perpetuity.

It is made available under a CC-BY-NC-ND 4.0 International license.

\section{Figures}

Figure 1: (a) Diagnosis and care cascade among GBMSM/TP living with HIV; (b) Log viral load median and distribution by level of diagnosis and care cascade engagement

Footnotes:

Footnote 1(a):

*Kenyan National HIV testing algorithm: Serial Determine Alere and First Response Rapid Diagnostic Tests

Point estimates are RDS adjusted and exclude seeds. Error bars represent $95 \%$ confidence intervals

\section{Footnote 2(b)}

Intervals: A to B: HIV positive only on GeneXpert; B to C HIV positive on RDT but participant not status aware; $C$ to $D$ Participant reports status awareness but reports no current use of ART; D Participants reports current use of ART.

Vertical bars represent interquartile range, white dots represent median log viral load. Median and category sample size stated in label. <LLD: below Lower Limit of Detection (40 copies/mm3). Pvalues from Kruskall-Wallis equality of populations rank test

Figure 2: (a) HIV care cascade measures by age group; (b) Log viral load median and distribution by age group

\section{Footnote 2(a)}

Point estimates are unadjusted for sampling strategy and exclude seeds

Error bars represent $95 \%$ confidence intervals

\section{Footnote 2(b)}

Vertical bars represent interquartile range, white dots represent median viral load (also stated in label)

<LLD: below Lower Limit of Detection (40 copies/mm3) 
medRxiv preprint doi: https://doi.org/10.1101/2021.06.23.21259373; this version posted June 28, 2021. The copyright holder for this preprint (which was not certified by peer review) is the author/funder, who has granted medRxiv a license to display the preprint in perpetuity.

It is made available under a CC-BY-NC-ND 4.0 International license.

Table 1: Sample sociodemographic characteristics. risk behaviour and sexually transmitted infections

\begin{tabular}{|c|c|c|c|}
\hline & $\mathrm{N}$ & Crude \% & $\begin{array}{c}\text { RDS \% } \\
\mathrm{N}=608(95 \% \mathrm{Cl})^{\dagger}\end{array}$ \\
\hline \multicolumn{4}{|l|}{ Age in years } \\
\hline $18-23$ & $225 / 618$ & 36.4 & $38.2(33.8-42.8)$ \\
\hline $23-26$ & $169 / 618$ & 27.4 & $27.2(23.4-31.5)$ \\
\hline $27-32$ & $136 / 618$ & 22.0 & $20.6(17.2-24.5)$ \\
\hline $33+$ & $88 / 618$ & 14.2 & $14.0(11.1-17.5)$ \\
\hline \multicolumn{4}{|l|}{ Employment } \\
\hline Salaried (full or part time) & $179 / 608$ & 29.4 & $28.1(24.1-32.4)$ \\
\hline Self employed & $159 / 608$ & 26.2 & $27.4(23.5-31.8)$ \\
\hline Unemployed & $247 / 608$ & 40.6 & $41.7(37.2-46.3)$ \\
\hline Other & $23 / 608$ & 3.8 & $2.9(1.7-4.7)$ \\
\hline \multicolumn{4}{|l|}{ Education } \\
\hline Primary & $111 / 611$ & 18.2 & $18.1(14.8-21.9)$ \\
\hline Secondary & $329 / 611$ & 53.9 & $55.0(50.4-59.6)$ \\
\hline Higher & $171 / 611$ & 28.0 & $26.9(23.0-31.1)$ \\
\hline \multicolumn{4}{|l|}{ Income (Kenya Shillings] } \\
\hline$<5 k$ & $224 / 574$ & 39.0 & $40.9(36.2-45.7)$ \\
\hline $5<10 k$ & $166 / 574$ & 28.9 & $27.7(23.6-32.1)$ \\
\hline $10 k+$ & $184 / 574$ & 32.1 & $31.5(27.2-36.1)$ \\
\hline \multicolumn{4}{|l|}{ Country of birth } \\
\hline Kenya & $484 / 607$ & 79.7 & $78.8(74.6-82.4)$ \\
\hline Other African country & $112 / 607$ & 18.5 & $19.8(16.3-23.9)$ \\
\hline Non-African country & $11 / 607$ & 1.8 & $1.4(0.7-2.9)$ \\
\hline \multicolumn{4}{|l|}{ Sexual identity } \\
\hline Gay/homosexual & $448 / 609$ & 73.6 & $73.2(69.0-77.2)$ \\
\hline Bisexual & $143 / 609$ & 23.5 & $23.4(19.7-27.6)$ \\
\hline Other & $18 / 609$ & 3.0 & $3.3(2.0-5.6)$ \\
\hline \multicolumn{4}{|l|}{ Gender identity } \\
\hline Cis-gender male & $522 / 618$ & 84.5 & $85.0(81.5-88.0)$ \\
\hline Transgender female & $70 / 618$ & 11.3 & $11.3(8.7-14.5)$ \\
\hline Other & $26 / 618$ & 4.2 & $3.7(2.6-5.7)$ \\
\hline \multirow{2}{*}{\multicolumn{4}{|c|}{$\begin{array}{l}\text { Sexual behaviour - male partners } \\
\text { Male sexual partners (last } 3 \text { months) }\end{array}$}} \\
\hline & & & \\
\hline None & $74 / 618$ & 12.0 & $12.5(9.7-15.9)$ \\
\hline $1-3$ & $405 / 618$ & 65.5 & $72.7(68.5-76.5)$ \\
\hline 4 or more & $139 / 618$ & 22.5 & $14.8(12.1-18.0)$ \\
\hline Sold sex (last 12months) & $297 / 613$ & 48.5 & $43.8(39.3-48.4)$ \\
\hline Paid for sex (last 12 months) & $177 / 614$ & 28.8 & $28.2(24.2-32.6)$ \\
\hline \multicolumn{4}{|l|}{ Anal intercourse with male partner (last 3 months) } \\
\hline None & $77 / 618$ & 12.5 & $13.1(10.2-16.5)$ \\
\hline Receptive only & $158 / 618$ & 25.6 & $24.8(21.1-29.0)$ \\
\hline Insertive only & $220 / 618$ & 35.6 & $37.9(33.5-42.5)$ \\
\hline Receptive and insertive & $163 / 618$ & 26.4 & $24.2(20.6-28.3)$ \\
\hline \multicolumn{4}{|l|}{ Condomless anal intercourse (last 3 months) } \\
\hline None & $353 / 618$ & 57.1 & $58.2(53.6-62.6)$ \\
\hline Receptive only & $90 / 618$ & 14.6 & $14.4(11.5-18.0)$ \\
\hline Insertive only & $90 / 618$ & 14.6 & $14.9(11.9-18.5)$ \\
\hline Both & $85 / 618$ & 13.8 & $12.5(9.8-15.8)$ \\
\hline $\begin{array}{l}\text { Condomless anal intercourse with male partners } \\
\text { (last } 3 \text { months) }\end{array}$ & $265 / 618$ & 42.9 & $41.8(37.4-46.4)$ \\
\hline \multicolumn{4}{|l|}{ Sexual behaviour - female partners } \\
\hline Female sexual partner (last 3 months) & $174 / 618$ & 28.2 & $28.3(24.4-32.7)$ \\
\hline Sold sex to female partner (last 12 months) & $58 / 615$ & 9.4 & $9.0(6.7-12.1)$ \\
\hline Paid for sex with female partner (last 12 months) & $67 / 614$ & 10.9 & $11.2(8.6-14.6)$ \\
\hline $\begin{array}{l}\text { Condomless intercourse with female partners (last } 3 \\
\text { months) }\end{array}$ & $94 / 618$ & 15.2 & $15.9(12.8-19.6)$ \\
\hline
\end{tabular}


medRxiv preprint doi: https://doi.org/10.1101/2021.06.23.21259373; this version posted June 28, 2021. The copyright holder for this preprint (which was not certified by peer review) is the author/funder, who has granted medRxiv a license to display the preprint in perpetuity.

\section{It is made available under a CC-BY-NC-ND 4.0 International license.}

\begin{tabular}{|c|c|c|c|}
\hline Forced to have sex against will (last 12 months) & $87 / 615$ & 14.1 & $13.1(10.3-16.5)$ \\
\hline Substance Use Behaviour & & & \\
\hline Alcohol use (last two weeks) & & & \\
\hline Never & $261 / 618$ & 42.2 & $45.1(40.6-49.7)$ \\
\hline Monthly & $269 / 618$ & 43.5 & $42.5(38.0-47.1)$ \\
\hline Weekly & $88 / 618$ & 14.2 & $12.4(9.8-15.7)$ \\
\hline Other substance use $(3 \mathrm{~m})^{*}$ & $51 / 618$ & 8.3 & $8.0(5.8-10.8)$ \\
\hline HIV & & & \\
\hline HIV-RNA [GeneXpert HIV-1 Qual] only & $2 / 617$ & 0.3 & $0.6(0.1-2.2)$ \\
\hline Rapid Test [Determine / First Response] & $184 / 617$ & 29.8 & $25.8(22.1-30.0)$ \\
\hline Total & $186 / 618$ & 30.1 & $26.4(22.6-30.6)$ \\
\hline Syphilis & & & \\
\hline Positive (TPHA+ / RPR >3] & $5 / 614$ & 0.8 & $1.1(0.4-2.8)$ \\
\hline Hepatitis B & & & \\
\hline Po sitive (HBsAg) & $30 / 614$ & 4.9 & $4.4(2.8-6.7)$ \\
\hline Hepatitis C & & & \\
\hline Positive (anti-HCV Ab) & $3 / 614$ & 0.5 & $0.4(0.1-1.7)$ \\
\hline Rectal STIs & & & \\
\hline Lab confirmed rectal $N$. gonnorhoeae & $76 / 611$ & 12.4 & $13.2(10.4-16.8)$ \\
\hline Lab confirmed rectal C. trachomatis & $53 / 611$ & 8.7 & $8.1(5.9-10.9)$ \\
\hline Self-reported rectal STI symptoms & $51 / 609$ & 8.4 & $8.6(6.3-11.6)$ \\
\hline Urethral STIs & & & \\
\hline Lab confirmed urethral $N$. gonnorhoeae & $27 / 614$ & 4.4 & $4.4(2.9-6.7)$ \\
\hline Lab confirmed urethral $C$. trachomatis & $39 / 614$ & 6.4 & $7.3(5.2-10.3)$ \\
\hline Self-reported urethral STI symptoms & $43 / 601$ & 7.2 & $6.4(4.5-9.0)$ \\
\hline
\end{tabular}

t: Seeds dropped and RDS-II weighting *Ecstacy, amphetimines, mephamphetamine, mephedrone, heroin, GHB, rohypnol, cocacine, crack cocaine, benzene, amyl nitrite 
Table 2: Associations with HIV status, GBMSM/TP, Nairobi 2017

\begin{tabular}{|c|c|c|c|c|c|c|c|c|c|}
\hline & & \multirow[b]{2}{*}{$\mathrm{n} / \mathrm{N}$} & \multirow{2}{*}{$\begin{array}{c}\text { HIV } \\
\text { prevalence } \\
\text { Crude \% } \\
\mathrm{N}=618\end{array}$} & \multicolumn{2}{|c|}{ HIV prevalence ratio (crude) } & \multicolumn{2}{|c|}{$\begin{array}{c}\text { HIV prevalence ratio with } \\
\text { sociodemographic adjustment } \\
\text { (model } 1)^{\text {政 }}\end{array}$} & \multicolumn{2}{|c|}{$\begin{array}{l}\text { HIV prevalence ratio with full } \\
\text { adjustment (model } 2)^{\ddagger}\end{array}$} \\
\hline & & & & $\mathrm{PR}(95 \% \mathrm{Cl})^{+}$ & $\begin{array}{l}\text { Wald } p \\
\text { value }\end{array}$ & aPR $(95 \% \mathrm{Cl})$ & $\begin{array}{l}\text { Wald } p \\
\text { value }\end{array}$ & aPR $(95 \% \mathrm{Cl})$ & $\begin{array}{l}\text { Wald } p \\
\text { value }\end{array}$ \\
\hline \multicolumn{10}{|c|}{ Sociodemographic characteristics } \\
\hline Age (years) & $\begin{array}{r}18-22 \\
23-26 \\
27-32 \\
33+\end{array}$ & $\begin{array}{c}34 / 225 \\
54 / 168 \\
51 / 136 \\
47 / 88\end{array}$ & $\begin{array}{l}15.1 \\
32.1 \\
37.5 \\
53.4\end{array}$ & $\begin{array}{c}\text { ref } \\
2.12(1.45-3.10) \\
2.45(1.68-3.59) \\
3.51(2.43-5.06)\end{array}$ & $<0.0001$ & $\begin{array}{c}\text { ref } \\
2.25(1.53-3.30) \\
2.72(1.83-4.03) \\
3.67(2.51-5.36)\end{array}$ & $<0.0001$ & $\begin{array}{c}\text { ref } \\
2.00(1.38-2.90) \\
2.54(1.72-3.75) \\
3.98(2.78-5.71)\end{array}$ & $<0.0001$ \\
\hline Employment & $\begin{array}{r}\text { Salaried } \\
\text { Self employed } \\
\text { Unemployed } \\
\text { Other }\end{array}$ & $\begin{array}{c}70 / 179 \\
45 / 159 \\
62 / 247 \\
6 / 23\end{array}$ & $\begin{array}{l}39.1 \\
28.3 \\
25.2 \\
26.1\end{array}$ & $\begin{array}{c}\text { ref } \\
\mathbf{0 . 7 5}(0.55-1.02) \\
\mathbf{0 . 6 6}(0.50-0.88) \\
0.68(0.33-1.38)\end{array}$ & $\begin{array}{l}0.068 \\
0.004 \\
0.285\end{array}$ & $\begin{array}{c}\text { ref } \\
\mathbf{0 . 7 3}(\mathbf{0 . 5 4 - 0 . 9 8 )} \\
0.83(0.63-1.10) \\
0.98(0.53-1.81)\end{array}$ & $\begin{array}{l}0.0341 \\
0.1911 \\
0.9874\end{array}$ & $\begin{array}{c}\text { ref } \\
0.80(0.60-1.07) \\
0.79(0.61-1.02) \\
1.00(0.57-1.77)\end{array}$ & $\begin{array}{l}0.1289 \\
0.0730 \\
0.9927\end{array}$ \\
\hline Education & $\begin{array}{r}\text { Primary } \\
\text { Secondary } \\
\text { Higher }\end{array}$ & $\begin{array}{l}42 / 111 \\
94 / 329 \\
49 / 171\end{array}$ & $\begin{array}{l}37.8 \\
28.6 \\
28.8\end{array}$ & $\begin{array}{c}\text { ref } \\
0.76(0.56-1.02) \\
0.78(0.55-1.09)\end{array}$ & $\begin{array}{l}0.0669 \\
0.1401\end{array}$ & $\begin{array}{c}\text { ref } \\
0.92(0.69-1.23) \\
0.81(0.58-1.12)\end{array}$ & $\begin{array}{l}0.5731 \\
0.1997\end{array}$ & $\begin{array}{c}\text { ref } \\
0.91(0.70-1.19) \\
0.78(0.58-1.05)\end{array}$ & $\begin{array}{l}0.4972 \\
0.0976\end{array}$ \\
\hline Country of birth & $\begin{array}{r}\text { Kenya } \\
\text { Other African country } \\
\text { Non-African country }\end{array}$ & $\begin{array}{c}163 / 484 \\
14 / 112 \\
4 / 11\end{array}$ & $\begin{array}{l}33.8 \\
12.5 \\
36.4\end{array}$ & $\begin{array}{c}\text { ref } \\
\mathbf{0 . 3 8}(\mathbf{0 . 2 3 - 0 . 6 3 )} \\
1.08(0.49-2.39)\end{array}$ & $\begin{array}{c}<0.001 \\
0.846\end{array}$ & $\begin{array}{c}\text { ref } \\
\mathbf{0 . 3 1}(\mathbf{0 . 1 8 - 0 . 5 2 )} \\
0.99(0.47-2.10)\end{array}$ & $\begin{array}{c}<0.0001 \\
0.9874\end{array}$ & $\begin{array}{c}\text { ref } \\
0.38(0.23-0.63) \\
1.13(0.54-2.38)\end{array}$ & $\begin{array}{l}\mathbf{0 . 0 0 0 1} \\
0.7455\end{array}$ \\
\hline Sexual identity & $\begin{array}{r}\text { Gay/homosexual } \\
\text { Bisexual } \\
\text { Other }\end{array}$ & $\begin{array}{c}140 / 448 \\
37 / 143 \\
6 / 18\end{array}$ & $\begin{array}{l}31.3 \\
25.9 \\
33.3\end{array}$ & $\begin{array}{c}\text { ref } \\
0.82(0.60-1.12) \\
1.06(0.54-2.07)\end{array}$ & $\begin{array}{l}0.215 \\
0.858\end{array}$ & - & - & - & - \\
\hline Gender identity & $\begin{array}{r}\text { Cis-gender male } \\
\text { Transgender female } \\
\text { Other }\end{array}$ & $\begin{array}{c}151 / 522 \\
28 / 70 \\
7 / 26\end{array}$ & $\begin{array}{l}29.0 \\
40.0 \\
26.9\end{array}$ & $\begin{array}{c}\text { ref } \\
1.40(1.02-1.93) \\
0.93(0.49-1.78)\end{array}$ & $\begin{array}{l}0.036 \\
0.830\end{array}$ & $\begin{array}{c}\text { ref } \\
1.50(1.09-2.05) \\
0.92(0.48-1.77)\end{array}$ & $\begin{array}{l}0.0115 \\
0.8114\end{array}$ & $\begin{array}{c}\text { ref } \\
1.18(0.86-1.61) \\
0.75(0.41-1.40)\end{array}$ & $\begin{array}{l}0.4200 \\
0.3606\end{array}$ \\
\hline \multicolumn{10}{|c|}{ Sexual behaviour - male partners } \\
\hline Male sexual partners $(3 \mathrm{~m})$ & $\begin{array}{r}\text { None } \\
1-3 \\
4 \text { or more }\end{array}$ & $\begin{array}{c}7 / 74 \\
122 / 405 \\
57 / 139\end{array}$ & $\begin{array}{c}9.5 \\
30.2 \\
41.0\end{array}$ & $\begin{array}{c}\text { ref } \\
3.10(1.51-6.38) \\
4.22(2.03-8.79)\end{array}$ & $<0.001$ & $\begin{array}{c}\text { ref } \\
2.57(1.30-5.09) \\
3.06(1.52-6.17)\end{array}$ & 0.0054 & $\begin{array}{c}\text { ref } \\
1.50(0.75-3.01) \\
1.62(0.79-3.34)\end{array}$ & 0.4028 \\
\hline $\begin{array}{r}\text { Sold sex to male partner } \\
\qquad(12 \mathrm{~m})\end{array}$ & $\begin{array}{l}\text { Yes } \\
\text { No }\end{array}$ & $\begin{array}{l}107 / 297 \\
78 / 316\end{array}$ & $\begin{array}{l}36.0 \\
24.8\end{array}$ & $\begin{array}{c}1.42(1.11-1.82) \\
\text { ref }\end{array}$ & 0.005 & $1.33(1.04-1.70)$ & 0.0228 & $\begin{array}{c}1.00(0.98-1.02) \\
\text { ref }\end{array}$ & 0.8295 \\
\hline $\begin{array}{r}\text { Paid for sex with male } \\
\text { partner }(12 \mathrm{~m})\end{array}$ & $\begin{array}{l}\text { Yes } \\
\text { No }\end{array}$ & $\begin{array}{c}61 / 177 \\
124 / 437\end{array}$ & $\begin{array}{l}34.5 \\
28.4\end{array}$ & $\begin{array}{c}1.19(0.92-1.54) \\
\text { ref }\end{array}$ & 0.177 & $1.05(0.82-1.33)$ & 0.7184 & - & - \\
\hline $\begin{array}{r}\text { Receptive anal intercourse } \\
\text { with male partner }(3 \mathrm{~m})\end{array}$ & $\begin{array}{l}\text { Yes } \\
\text { No }\end{array}$ & $\begin{array}{c}139 / 321 \\
47 / 297\end{array}$ & $\begin{array}{l}43.4 \\
15.8\end{array}$ & $\begin{array}{c}2.82(2.10-3.80) \\
\text { ref }\end{array}$ & $<0.001$ & $2.46(1.84-3.28)$ & $<0.0001$ & $\begin{array}{c}2.16(1.59-2.93) \\
\text { ref }\end{array}$ & $<0.0001$ \\
\hline Insertive anal intercourse & Yes & $118 / 383$ & 30.9 & $1.04(0.81-1.34)$ & 0.765 & $1.02(0.80-1.31)$ & 0.8424 & - & - \\
\hline
\end{tabular}




\begin{tabular}{|c|c|c|c|c|c|c|c|c|c|}
\hline with male partner $(3 \mathrm{~m})$ & No & $68 / 235$ & 28.9 & ref & & & & & \\
\hline $\begin{array}{l}\text { Condomless anal } \\
\text { intercourse }(3 \mathrm{~m})\end{array}$ & $\begin{array}{l}\text { Yes } \\
\text { No }\end{array}$ & $\begin{array}{l}97 / 265 \\
89 / 353 \\
\end{array}$ & $\begin{array}{l}36.6 \\
25.3 \\
\end{array}$ & $\begin{array}{c}1.40(1.10-1.78) \\
\text { ref }\end{array}$ & 0.006 & $1.37(1.08-1.73)$ & 0.0093 & $\begin{array}{c}1.20(0.94-1.52) \\
\text { ref }\end{array}$ & 0.1454 \\
\hline \multicolumn{10}{|c|}{ Sexual behaviour - female partners } \\
\hline Female sexual partner $(3 \mathrm{~m})$ & $\begin{array}{l}\text { Yes } \\
\text { No }\end{array}$ & $\begin{array}{c}45 / 174 \\
141 / 444 \\
\end{array}$ & $\begin{array}{l}25.9 \\
31.8\end{array}$ & $\begin{array}{c}0.83(0.62-1.11) \\
\text { ref }\end{array}$ & 0.207 & $0.68(0.51-0.89)$ & 0.0047 & $\begin{array}{c}1.03(0.72-1.47) \\
\text { ref }\end{array}$ & 0.8826 \\
\hline $\begin{array}{r}\text { Sold sex to female partner } \\
(12 \mathrm{~m})\end{array}$ & $\begin{array}{l}\text { Yes } \\
\text { No }\end{array}$ & $\begin{array}{c}18 / 58 \\
168 / 557 \\
\end{array}$ & $\begin{array}{l}31.0 \\
30.2\end{array}$ & $\begin{array}{c}1.03(0.69-1.54) \\
\text { ref }\end{array}$ & 0.890 & $0.92(0.62-1.36)$ & 0.6630 & - & - \\
\hline $\begin{array}{r}\text { Paid for sex with female } \\
\text { partner }(12 \mathrm{~m})\end{array}$ & $\begin{array}{l}\text { Yes } \\
\text { No }\end{array}$ & $\begin{array}{c}17 / 67 \\
168 / 547 \\
\end{array}$ & $\begin{array}{l}25.4 \\
30.8\end{array}$ & $\begin{array}{c}0.84(0.55-1.29) \\
\text { ref }\end{array}$ & 0.425 & $0.69(0.46-1.05)$ & 0.0859 & $\begin{array}{c}1.00(0.98-1.02) \\
\text { ref }\end{array}$ & 0.9082 \\
\hline $\begin{array}{r}\text { Condomless intercourse } \\
(3 \mathrm{~m})\end{array}$ & $\begin{array}{l}\text { Yes } \\
\text { No }\end{array}$ & $\begin{array}{c}22 / 94 \\
164 / 524\end{array}$ & $\begin{array}{l}23.4 \\
31.4\end{array}$ & $\begin{array}{c}0.76(0.52-1.13) \\
\text { ref }\end{array}$ & 0.174 & $0.60(0.41-0.90)$ & 0.0085 & $\begin{array}{c}0.56(0.33-0.94) \\
\text { ref }\end{array}$ & 0.0264 \\
\hline \multicolumn{10}{|l|}{ Sexual violence } \\
\hline $\begin{array}{r}\text { Forced to have sex against } \\
\text { will }(12 \mathrm{~m})\end{array}$ & $\begin{array}{l}\text { Yes } \\
\text { No }\end{array}$ & $\begin{array}{c}26 / 87 \\
160 / 528 \\
\end{array}$ & $\begin{array}{l}29.9 \\
30.4 \\
\end{array}$ & $\begin{array}{c}0.98(0.70-1.39) \\
\text { ref }\end{array}$ & 0.928 & $1.15(0.83-1.58)$ & 0.4034 & - & - \\
\hline \multicolumn{10}{|l|}{ Substance Use Behaviour } \\
\hline Alcohol use (current) & $\begin{array}{r}\text { Never } \\
\text { Monthly } \\
\text { Weekly }\end{array}$ & $\begin{array}{c}87 / 261 \\
77 / 269 \\
22 / 88 \\
\end{array}$ & $\begin{array}{l}33.3 \\
28.7 \\
25.0 \\
\end{array}$ & $\begin{array}{c}\text { Ref } \\
0.86(0.67-1.12) \\
0.75(0.50-1.12)\end{array}$ & 0.2800 & $\begin{array}{l}0.85(0.67-1.09) \\
0.69(0.47-1.00)\end{array}$ & 0.1141 & - & - \\
\hline Other substance use $(3 m)^{*}$ & $\begin{array}{l}\text { Yes } \\
\text { No }\end{array}$ & $\begin{array}{c}17 / 51 \\
169 / 567\end{array}$ & $\begin{array}{l}33.3 \\
29.9\end{array}$ & $\begin{array}{c}1.09(0.72-1.66) \\
\text { ref }\end{array}$ & 0.686 & $1.22(0.86-1.74)$ & 0.2708 & - & - \\
\hline
\end{tabular}

PR: Prevalence Ratio aPR: Confounder-adjusted Prevalence Ratio +Crude bivariable Poisson regression with robust estimation of variance ++ Multiivariable Poisson regression with robust estimation of variance and adjustment for sociodemographic factors (age, education and sexual identity) with seeds excluded $¥$ Multiivariable Poisson regression with robust estimation of variance and adjustment for tabled sociodemographic and behavioural factors with seeds excluded *Ecstacy, amphetimines, mephamphetamine, mephedrone, heroin, GHB, rohypnol, cocacine, crack cocaine, benzene, amyl nitrite 
Table 3: Associations with detectable VL among participants living with HIV, GBMSM/TP, Nairobi 2017

\begin{tabular}{|c|c|c|c|c|c|c|c|c|c|}
\hline & & \multirow[b]{2}{*}{$\mathrm{n} / \mathrm{N}$} & \multirow{2}{*}{$\begin{array}{c}\begin{array}{c}\text { Prevalence of } \\
\text { detectable } \\
\text { viral load }>50 \\
\text { copies } / \mathrm{ml}\end{array} \\
\begin{array}{c}\text { Crude } \% \\
\mathrm{~N}=186\end{array}\end{array}$} & \multicolumn{2}{|c|}{$\begin{array}{l}\text { Viral detection prevalence ratio } \\
\qquad{\text { (crude })^{+}}^{+}\end{array}$} & \multicolumn{2}{|c|}{$\begin{array}{l}\text { Viral detection prevalence } \\
\text { ratio with sociodemographic } \\
\text { ad justment (model } 1)^{\circledR \dagger}\end{array}$} & \multicolumn{2}{|c|}{$\begin{array}{l}\text { Viral detection ratio with full } \\
\text { adjustment (model } 2)^{\ddagger}\end{array}$} \\
\hline & & & & $\mathrm{PR}(95 \% \mathrm{Cl})$ & $\begin{array}{l}\text { Wald } p \\
\text { value }\end{array}$ & aPR $(95 \% \mathrm{Cl})$ & $\begin{array}{l}\text { Wald } p \\
\text { value }\end{array}$ & aPR $(95 \% \mathrm{Cl})$ & $\begin{array}{l}\text { Wald } p \\
\text { value }\end{array}$ \\
\hline \multicolumn{10}{|c|}{ Sociodemographic characteristics } \\
\hline Age (years) & $\begin{array}{r}18-22 \\
23-26 \\
27-32 \\
33+\end{array}$ & $\begin{array}{l}25 / 34 \\
29 / 54 \\
24 / 51 \\
16 / 47\end{array}$ & $\begin{array}{l}73.5 \\
53.7 \\
47.1 \\
34.0\end{array}$ & $\begin{array}{c}\text { ref } \\
0.73(0.53-1.01) \\
0.64(0.45-0.92) \\
0.44(0.28-0.70)\end{array}$ & 0.0020 & $\begin{array}{c}\text { ref } \\
0.74(0.53-1.04) \\
0.65(0.45-0.94) \\
0.46(0.29-0.74)\end{array}$ & 0.0052 & $\begin{array}{c}\text { ref } \\
0.84(0.61-1.16) \\
0.71(0.50-1.02) \\
0.46(0.29-0.74)\end{array}$ & 0.0103 \\
\hline Employment & $\begin{array}{r}\text { Salaried } \\
\text { Self employed } \\
\text { Unemployed } \\
\text { Other }\end{array}$ & $\begin{array}{l}37 / 70 \\
21 / 45 \\
33 / 62 \\
2 / 6\end{array}$ & $\begin{array}{l}72.9 \\
46.7 \\
53.2 \\
33.3\end{array}$ & $\begin{array}{c}\text { Ref } \\
0.89(0.61-1.32) \\
1.02(0.73-1.41) \\
0.64(0.20-2.03)\end{array}$ & $\begin{array}{l}0.569 \\
0.911 \\
0.447\end{array}$ & $\begin{array}{l}- \\
- \\
- \\
-\end{array}$ & $\begin{array}{l}- \\
- \\
-\end{array}$ & $\begin{array}{l}- \\
- \\
- \\
-\end{array}$ & $\begin{array}{l}- \\
- \\
- \\
-\end{array}$ \\
\hline Education & $\begin{array}{r}\text { Primary } \\
\text { Secondary } \\
\text { Higher }\end{array}$ & $\begin{array}{l}27 / 42 \\
47 / 94 \\
20 / 49 \\
\end{array}$ & $\begin{array}{l}64.3 \\
50.0 \\
40.8 \\
\end{array}$ & $\begin{array}{c}\text { ref } \\
0.79(0.58-1.08) \\
\mathbf{0 . 6 4}(\mathbf{0 . 4 3 - 0 . 9 7 )} \\
\end{array}$ & $\begin{array}{l}0.1334 \\
0.0355\end{array}$ & $\begin{array}{c}\text { ref } \\
0.77(0.56-1.05) \\
\mathbf{0 . 6 4}(\mathbf{0 . 4 2 - 0 . 9 7 )} \\
\end{array}$ & $\begin{array}{c}\text { ref } \\
0.1015 \\
\mathbf{0 . 0 3 7 1}\end{array}$ & $\begin{array}{c}\text { ref } \\
0.81(0.60-1.08) \\
0.68(0.46-1.00) \\
\end{array}$ & $\begin{array}{l}0.1597 \\
0.0501\end{array}$ \\
\hline Country of birth & $\begin{array}{r}\text { Kenya } \\
\text { Other African country } \\
\text { Non-African country }\end{array}$ & $\begin{array}{c}86 / 163 \\
6 / 14 \\
1 / 4\end{array}$ & $\begin{array}{l}52.8 \\
42.9 \\
25.0\end{array}$ & $\begin{array}{c}\text { ref } \\
0.82(0.44-1.52) \\
0.48(0.09-2.63)\end{array}$ & $\begin{array}{l}0.524 \\
0.395\end{array}$ & $\begin{array}{l}- \\
- \\
-\end{array}$ & $\begin{array}{l}- \\
- \\
-\end{array}$ & $\begin{array}{l}- \\
- \\
-\end{array}$ & $\begin{array}{l}- \\
- \\
-\end{array}$ \\
\hline Sexual identity & $\begin{array}{r}\text { Gay/homosexual } \\
\text { Bisexual } \\
\text { Other }\end{array}$ & $\begin{array}{c}77 / 140 \\
13 / 37 \\
4 / 6 \\
\end{array}$ & $\begin{array}{l}55.0 \\
35.1 \\
66.7 \\
\end{array}$ & $\begin{array}{c}\text { ref } \\
0.66(0.42-1.05) \\
1.23(0.68-2.21) \\
\end{array}$ & $\begin{array}{l}0.083 \\
0.496\end{array}$ & $\begin{array}{c}\text { ref } \\
0.78(0.50-1.22) \\
1.31(0.78-2.18) \\
\end{array}$ & $\begin{array}{l}0.2803 \\
0.3065\end{array}$ & $\begin{array}{c}\text { ref } \\
0.68(0.45-1.03) \\
1.33(0.80-2.21) \\
\end{array}$ & $\begin{array}{l}0.0646 \\
0.2741\end{array}$ \\
\hline Gender identity & $\begin{array}{r}\text { Cis-gender male } \\
\text { Transgender female } \\
\text { Other }\end{array}$ & $\begin{array}{c}76 / 151 \\
16 / 28 \\
2 / 7\end{array}$ & $\begin{array}{l}50.3 \\
57.1 \\
28.6\end{array}$ & $\begin{array}{c}\text { ref } \\
1.14(0.80-1.64) \\
0.57(0.17-1.87)\end{array}$ & $\begin{array}{l}0.467 \\
0.355\end{array}$ & $\begin{array}{l}- \\
- \\
-\end{array}$ & $\begin{array}{l}- \\
- \\
-\end{array}$ & $\begin{array}{l}- \\
- \\
-\end{array}$ & $\begin{array}{l}- \\
- \\
-\end{array}$ \\
\hline \multicolumn{10}{|c|}{ Sexual behaviour - male partners } \\
\hline Male sexual partners $(3 \mathrm{~m})$ & $\begin{array}{r}\text { None } \\
1-3 \\
4 \text { ormore }\end{array}$ & $\begin{array}{c}3 / 7 \\
71 / 122 \\
20 / 57\end{array}$ & $\begin{array}{l}42.9 \\
58.2 \\
35.1\end{array}$ & $\begin{array}{c}\text { ref } \\
1.35(0.56-3.23) \\
0.81(0.32-2.05)\end{array}$ & 0.0336 & $\begin{array}{c}\text { ref } \\
1.04(0.48-2.24) \\
0.68(0.29-1.58)\end{array}$ & 0.1202 & $\begin{array}{l}- \\
- \\
-\end{array}$ & - \\
\hline $\begin{array}{r}\text { Sold sex to male partner } \\
(12 \mathrm{~m})\end{array}$ & $\begin{array}{r}\text { Yes } \\
\text { No }\end{array}$ & $\begin{array}{c}46 / 107 \\
48 / 78\end{array}$ & $\begin{array}{l}43.0 \\
61.5\end{array}$ & $\begin{array}{l}0.69(0.52-0.91) \\
\text { ref }\end{array}$ & 0.010 & $\begin{array}{l}0.66(0.50-0.86) \\
\text { ref }\end{array}$ & 0.0028 & $\begin{array}{c}0.55(0.41-0.75) \\
\text { ref }\end{array}$ & 0.0001 \\
\hline
\end{tabular}




\begin{tabular}{|c|c|c|c|c|c|c|c|c|c|}
\hline $\begin{array}{r}\text { Paid for sex with male } \\
\text { partner }(12 \mathrm{~m})\end{array}$ & $\begin{array}{l}\text { Yes } \\
\text { No }\end{array}$ & $\begin{array}{c}37 / 61 \\
57 / 124\end{array}$ & $\begin{array}{l}60.7 \\
46.0\end{array}$ & $\begin{array}{c}1.28(0.96-1.70) \\
\text { Ref }\end{array}$ & 0.090 & $\begin{array}{c}1.44(1.10-1.88) \\
\text { ref }\end{array}$ & 0.0084 & $\begin{array}{l}1.72(1.25-2.35) \\
\text { ref }\end{array}$ & 0.0008 \\
\hline $\begin{array}{r}\text { Receptive anal intercourse } \\
\text { with male partner }(3 \mathrm{~m})\end{array}$ & $\begin{array}{l}\text { Yes } \\
\text { No }\end{array}$ & $\begin{array}{c}73 / 139 \\
21 / 47\end{array}$ & $\begin{array}{l}52.5 \\
44.7\end{array}$ & $\begin{array}{c}1.25(0.86-1.83) \\
\text { ref }\end{array}$ & 0.242 & $\begin{array}{c}1.04(0.72-1.50) \\
\text { ref }\end{array}$ & 0.8420 & $\begin{array}{l}- \\
-\end{array}$ & - \\
\hline $\begin{array}{r}\text { Insertive anal intercourse } \\
\text { with male partner }(3 \mathrm{~m})\end{array}$ & $\begin{array}{l}\text { Yes } \\
\text { No }\end{array}$ & $\begin{array}{c}59 / 118 \\
35 / 68\end{array}$ & $\begin{array}{l}50.0 \\
51.5\end{array}$ & $\begin{array}{c}0.96(0.72-1.29) \\
\text { ref }\end{array}$ & 0.803 & $\begin{array}{c}1.07(0.81-1.43) \\
\text { ref }\end{array}$ & 0.6192 & $\begin{array}{l}- \\
-\end{array}$ & - \\
\hline $\begin{array}{l}\text { Condomless anal } \\
\text { intercourse }(3 \mathrm{~m})\end{array}$ & $\begin{array}{l}\text { Yes } \\
\text { No }\end{array}$ & $\begin{array}{l}56 / 97 \\
38 / 89\end{array}$ & $\begin{array}{l}57.7 \\
42.7\end{array}$ & $\begin{array}{c}1.35(1.00-1.81) \\
\text { ref }\end{array}$ & 0.051 & $\begin{array}{c}1.30(0.97-1.74) \\
\text { ref }\end{array}$ & 0.0740 & $\begin{array}{c}1.24(0.95-1.63) \\
\text { ref }\end{array}$ & 0.1166 \\
\hline \multicolumn{10}{|c|}{ Sexual behaviour - female partners } \\
\hline Female sexual partner $(3 \mathrm{~m})$ & $\begin{array}{l}\text { Yes } \\
\text { No }\end{array}$ & $\begin{array}{c}24 / 45 \\
70 / 141\end{array}$ & $\begin{array}{l}53.3 \\
49.7\end{array}$ & $\begin{array}{c}1.08(0.78-1.49) \\
\text { ref }\end{array}$ & 0.630 & $\begin{array}{c}1.26(0.94-1.67) \\
\text { ref }\end{array}$ & 0.1164 & $\begin{array}{l}- \\
-\end{array}$ & $\begin{array}{l}- \\
-\end{array}$ \\
\hline $\begin{array}{r}\text { Sold sex to female partner } \\
(12 \mathrm{~m})\end{array}$ & $\begin{array}{l}\text { Yes } \\
\text { No }\end{array}$ & $\begin{array}{c}9 / 18 \\
85 / 168\end{array}$ & $\begin{array}{l}50.0 \\
50.6\end{array}$ & $\begin{array}{c}0.99(0.61-1.62) \\
\text { ref }\end{array}$ & 0.981 & $\begin{array}{c}0.96(0.65-1.41) \\
\text { ref }\end{array}$ & 0.8344 & $\begin{array}{l}- \\
-\end{array}$ & $\begin{array}{l}- \\
-\end{array}$ \\
\hline $\begin{array}{r}\text { Paid for sex with female } \\
\text { partner }(12 \mathrm{~m})\end{array}$ & $\begin{array}{l}\text { Yes } \\
\text { No }\end{array}$ & $\begin{array}{c}14 / 17 \\
80 / 168\end{array}$ & $\begin{array}{l}82.4 \\
47.6\end{array}$ & $\begin{array}{l}1.74(1.33-2.29) \\
\text { ref }\end{array}$ & $<0.001$ & $\begin{array}{c}1.64(1.26-2.11) \\
\text { ref }\end{array}$ & 0.0002 & $\begin{array}{c}1.22(0.90-1.66) \\
\text { ref }\end{array}$ & 0.1912 \\
\hline $\begin{array}{r}\text { Condomless intercourse } \\
3 \mathrm{~m}\end{array}$ & $\begin{array}{l}\text { Yes } \\
\text { No }\end{array}$ & $\begin{array}{c}14 / 22 \\
80 / 164\end{array}$ & $\begin{array}{l}63.6 \\
48.8\end{array}$ & $\begin{array}{c}1.31(0.92-1.87) \\
\text { ref }\end{array}$ & 0.132 & $\begin{array}{c}1.62(1.19-2.21) \\
\text { ref }\end{array}$ & 0.0023 & $\begin{array}{c}1.37(0.96-1.95) \\
\text { ref }\end{array}$ & 0.0789 \\
\hline \multicolumn{10}{|l|}{ Sexual violence } \\
\hline $\begin{array}{r}\text { Forced to have sex against } \\
\text { will }(12 \mathrm{~m})\end{array}$ & $\begin{array}{l}\text { Yes } \\
\text { No }\end{array}$ & $\begin{array}{c}11 / 26 \\
83 / 160\end{array}$ & $\begin{array}{l}42.3 \\
51.9\end{array}$ & $\begin{array}{l}0.82(0.51-1.32) \\
\text { ref }\end{array}$ & 0.413 & $\begin{array}{c}0.83(0.55-1.28) \\
\text { ref }\end{array}$ & 0.4022 & $\begin{array}{l}- \\
-\end{array}$ & $\begin{array}{l}- \\
-\end{array}$ \\
\hline \multicolumn{10}{|l|}{ Substance Use Behaviour } \\
\hline Alcohol use (current) & $\begin{array}{r}\text { Never } \\
\text { Monthly } \\
\text { Weekly }\end{array}$ & $\begin{array}{c}47 / 87 \\
3 / 77 \\
10 / 22 \\
\end{array}$ & $\begin{array}{l}54.0 \\
48.1 \\
45.5\end{array}$ & $\begin{array}{c}\text { ref } \\
0.90(0.66-1.22) \\
0.85(0.52-1.40)\end{array}$ & 0.7032 & $\begin{array}{c}\text { ref } \\
0.94(0.70-1.26) \\
0.90(0.56-1.45)\end{array}$ & 0.8611 & $\begin{array}{l}- \\
- \\
-\end{array}$ & $\begin{array}{l}- \\
- \\
-\end{array}$ \\
\hline Other substance use $(3 \mathrm{~m})^{*}$ & $\begin{array}{l}\text { Yes } \\
\text { No }\end{array}$ & $\begin{array}{c}11 / 17 \\
83 / 169\end{array}$ & $\begin{array}{l}64.7 \\
49.1\end{array}$ & $\begin{array}{c}1.27(0.84-1.92) \\
\text { ref }\end{array}$ & 0.250 & $\begin{array}{c}1.28(0.85-1.94) \\
\text { ref }\end{array}$ & 0.2425 & $\begin{array}{l}- \\
-\end{array}$ & $\begin{array}{l}- \\
-\end{array}$ \\
\hline
\end{tabular}

adjustment for sociodemographic factors (age, education and sexual identity) with seeds excluded $\ddagger$ Multiivariable Poisson regression with robust estimation of variance and adjustment for tabled sociodemographic and behavioural factors with seeds excluded *Ecstacy, amphetimines, mephamphetamine, mephedrone, heroin, GHB, rohypnol, cocacine, crack cocaine, benzene, amyl nitrite 
medRxiv preprint doi: https://doi.org/10.1101/2021.06.23.21259373; this version posted June 28, 2021. The copyright holder for this preprint (which was not certified by peer review) is the author/funder, who has granted medRxiv a license to display the preprint in perpetuity.

It is made available under a CC-BY-NC-ND 4.0 International license .

1. Beyrer C, Baral SD, van Griensven F, et al. Global epidemiology of HIV infection in men who have sex with men. Lancet. Jul 28 2012;380(9839):367-377.

2. Baral SD, Poteat T, Stromdahl S, Wirtz AL, Guadamuz TE, Beyrer C. Worldwide burden of HIV in transgender women: a systematic review and meta-analysis. Lancet Infect Dis. Mar 2013;13(3):214-222.

3. Poteat T, Scheim A, Xavier J, Reisner S, Baral S. Global Epidemiology of HIV Infection and Related Syndemics Affecting Transgender People. J Acquir Immune Defic Syndr. Aug 15 2016;72 Suppl 3:S210-219.

4. Poteat T, Ackerman B, Diouf D, et al. HIV prevalence and behavioral and psychosocial factors among transgender women and cisgender men who have sex with men in 8 African countries: A cross-sectional analysis. PLoS Medicine. Nov 2017;14(11).

5. Smith AD, Tapsoba P, Peshu N, Sanders EJ, Jaffe HW. Men who have sex with men and HIV/AIDS in sub-Saharan Africa. Lancet. 2009;374:416-422.

6. Pew Research Center. The Global Divide on Homosexuality Persists: Pew Research Center;2020.

7. UNAIDS. The Gap Report. Geneva: UNAIDS;2014.

8. Risher K, Mayer KH, Beyrer C. HIV treatment cascade in MSM, people who inject drugs, and sex workers. Current opinion in HIV and AIDS. 2015;10(6):420-429.

9. Stannah J, Dale E, Elmes J, Staunton R, Boily MC, Mitchell K. Sub-optimal engagement of African MSM in the HIV treatment cascade: a systematic review and meta-analysis. HIV R4P. Madrid, Spain2018.

10. Gupta S, Granich R. National HIV Care Continua for Key Populations. J Int Assoc Provid AIDS Care. Mar/Apr 2017;16(2):125-132.

11. Mwau M, Syeunda CA, Adhiambo M, et al. Scale-up of Kenya's national HIV viral load program: Findings and lessons learned. PLoS One. 2018;13(1):e0190659.

12. National AIDS and STI Control Programme. KENPHIA 2018 Preliminary Report. Nairobi: NASCOP;2020.

13. Muraguri N, Tun W, Okal J, et al. HIV and STI prevalence and risk factors among male sex workers and other men who have sex with men in Nairobi, Kenya. Journal of Acquired Immune Deficiency Syndromes: JAIDS. 2015;68:91-96.

14. Ministry of Health, National AIDS and STI Control Programme. Guidelines on the use of antiretroviral drugs for treating and preventing HIV infection in Kenya. Nairobi, Kenya: Ministry of Health;2016.

15. WHO. Consolidated Guidlines on HIV prevention, diagnosis, treatment and care for key populations: 2016 update. Geneva, Switzerland: WHO;2016.

16. Heckathorn DD. Respondent-driven sampling: a new approach to the study of hidden populations. Social Problems. 1997;44(2):174-199.

17. Lyons $C$, Stahlman S, Holland C, et al. Stigma and outness about sexual behaviors among cisgender men who have sex with men and transgender women in Eswatini: a latent class analysis. BMC Infect Dis. Mar 5 2019;19(1):211.

18. Stahlman S, Hargreaves JR, Sprague L, Stangl AL, Baral SD. Measuring Sexual Behavior Stigma to Inform Effective HIV Prevention and Treatment Programs for Key Populations. JMIR Public Health Surveill. Apr 26 2017;3(2):e23.

19. Babor T, Higgins-Biddle J, Saunders J, Monteiro M. AUDIT: The Alcohol Use Disorders Identification Test. Guidlines for use in primary care. 2nd Edition. Geneva: WHO;2001.

20. National AIDS and STI Control Programme. Guidelines for HIV testing services in Kenya. Nairobi, Kenya: Government of Kenya;2015. 
medRxiv preprint doi: https://doi.org/10.1101/2021.06.23.21259373; this version posted June 28, 2021. The copyright holder for this preprint (which was not certified by peer review) is the author/funder, who has granted medRxiv a license to display the preprint in perpetuity.

It is made available under a CC-BY-NC-ND 4.0 International license .

21. Centers for Disease Control. Understanding the HIV Care Continuum,. Atlanta, Georgia: Division of HIV/AIDS Preventon, National Center for HIV/AIDS, Viral Hepatitis, STD, and TB Prevention, CDC;2017.

22. Handcock MS, Fellows IE, Gile KJ. RDS: Respondent-Driven Sampling 2012; https://CRAN.Rproject.org/package=RDS. Accessed 30 Oct, 2020.

23. Gile KJ, Johnston LG, Salganik MJ. Diagnostics for Respondent-driven Sampling. I R Stat Soc Ser A Stat Soc. Jan 2015;178(1):241-269.

24. Volz E, Heckathorn DD. Probability Based Estimation Theory for Respondent Driven Sampling. Journal of Official Statistics,. 2008;24(1):79-97.

25. Huber PJ. The behavior of maximum likelihood estimates under non-standard conditions. Berkeley, CA: University of California Press;1967.

26. Barros AJ, Hirakata VN. Alternatives for logistic regression in cross-sectional studies: an empirical comparison of models that directly estimate the prevalence ratio. BMC Med Res Methodol. Oct 20 2003;3:21.

27. Avery L, Rotondi N, McKnight C, Firestone M, Smylie J, Rotondi M. Unweighted regression models perform better than weighted regression techniques for respondent-driven sampling data: results from a simulation study. BMC Med Res Methodol. Oct 29 2019;19(1):202.

28. Singh $\mathrm{K}$, Brodish $\mathrm{P}, \mathrm{Mbai} F$, et al. A venue-based approach to reaching MSM, IDUs and the general population with VCT: a three study site in Kenya. AIDS \& Behavior. 2012;16:818-828.

29. Sandfort TGM, Dominguez K, Kayange N, et al. HIV testing and the HIV care continuum among sub-Saharan African men who have sex with men and transgender women screened for participation in HPTN 075. PLoS One. 2019;14(5):e0217501.

30. Were D, Musau A, Mutegi J, et al. Using a HIV prevention cascade for identifying missed opportunities in PrEP delivery in Kenya: results from a programmatic surveillance study. J Int AIDS Soc. Jun 2020;23 Suppl 3:e25537.

31. Ayala G, Makofane K, Santos G-M, et al. HIV treatment cascades that leak: correlates of drop-off from the HIV care continuum among men who have sex with men worldwide. $J$ AIDS Clin Res. 2014;5(8).

32. O'Halloran C, Sun S, Nash S, et al. HIV in the United Kingdom: Towards Zero 2030. London: Public Health England;2019.

33. Ramadhani HO, Crowell TA, Nowak RG, et al. Association of age with healthcare needs and engagement among Nigerian men who have sex with men and transgender women: crosssectional and longitudinal analyses from an observational cohort. Journal of the International AIDS Society. 2020;23(S6):e25599.

34. Baggaley R, Armstrong A, Dodd Z, Ngoksin E, Krug A. Young key populations and HIV: a special emphasis and consideration in the new WHO Consolidated Guidelines on HIV Prevention, Diagnosis, Treatment and Care for Key Populations. J Int AIDS Soc. 2015;18(2 Suppl 1):19438.

35. Pettifor A, Stoner M, Pike C, Bekker L-G. Adolescent lives matter: preventing HIV in adolescents. Current Opinion in HIV and AIDS. 2018;13(3):265-273.

36. Bernstein KT, Marcus JL, Nieri G, Philip SS, Klausner JD. Rectal Gonorrhea and Chlamydia Reinfection Is Associated With Increased Risk of HIV Seroconversion. JAIDS Journal of Acquired Immune Deficiency Syndromes. 2010;53(4):537-543.

37. Shah NS, Kim E, de Maria Hernández Ayala F, et al. Performance and comparison of selfreported STI symptoms among high-risk populations - MSM, sex workers, persons living with HIV/AIDS - in El Salvador. International journal of STD \& AIDS. 2014;25(14):984-991.

38. Sanders EJ, Thiong, o AN, et al. High prevalence of \&lt;em\&gt;Chlamydia trachomatis\&lt;/em\&gt; and \&lt;em\&gt;Neisseria gonorrhoeae\&lt;/em\&gt; infections among HIV-1 negative men who have sex with men in coastal Kenya. Sexually Transmitted Infections. 2010;86(6):440. 
medRxiv preprint doi: https://doi.org/10.1101/2021.06.23.21259373; this version posted June 28, 2021. The copyright holder for this preprint (which was not certified by peer review) is the author/funder, who has granted medRxiv a license to display the preprint in perpetuity. It is made available under a CC-BY-NC-ND 4.0 International license.

39. Palmer S, Dijkstra M, Ket JC, et al. Acute and early HIV infection screening among men who have sex with men, a systematic review and meta-analysis. Journal of the International AIDS Society. 2020;23(S6):e25590.

40. Fogel JM, Sandfort T, Zhang Y, et al. Accuracy of Self-Reported HIV Status Among African Men and Transgender Women Who Have Sex with Men Who were Screened for Participation in a Research Study: HPTN 075. AIDS Behav. Jan 2019;23(1):289-294.

41. Mooney AC, Campbell CK, Ratlhagana MJ, et al. Beyond Social Desirability Bias: Investigating Inconsistencies in Self-Reported HIV Testing and Treatment Behaviors Among HIV-Positive Adults in North West Province, South Africa. AIDS Behav. Jul 2018;22(7):2368-2379. 


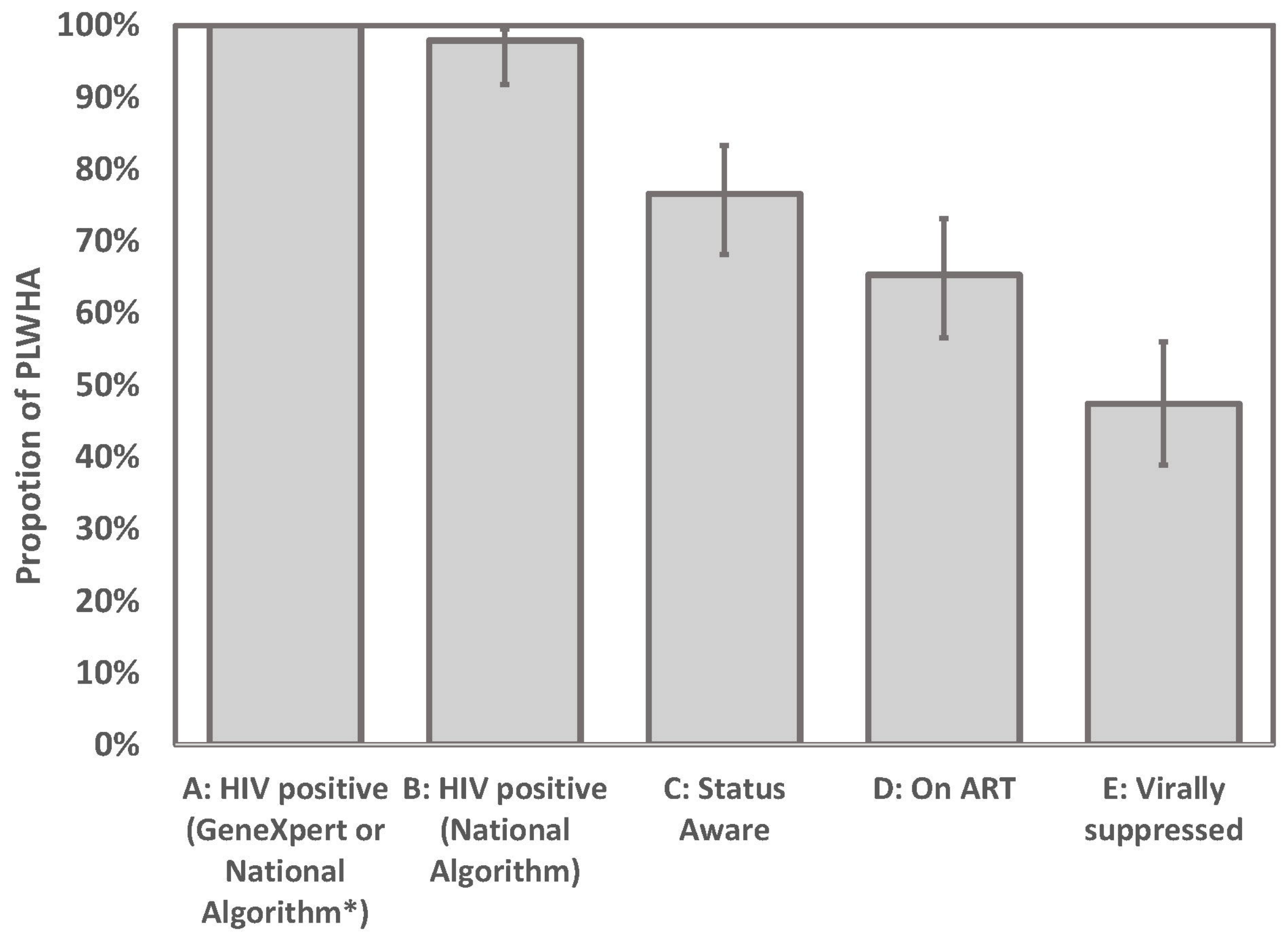




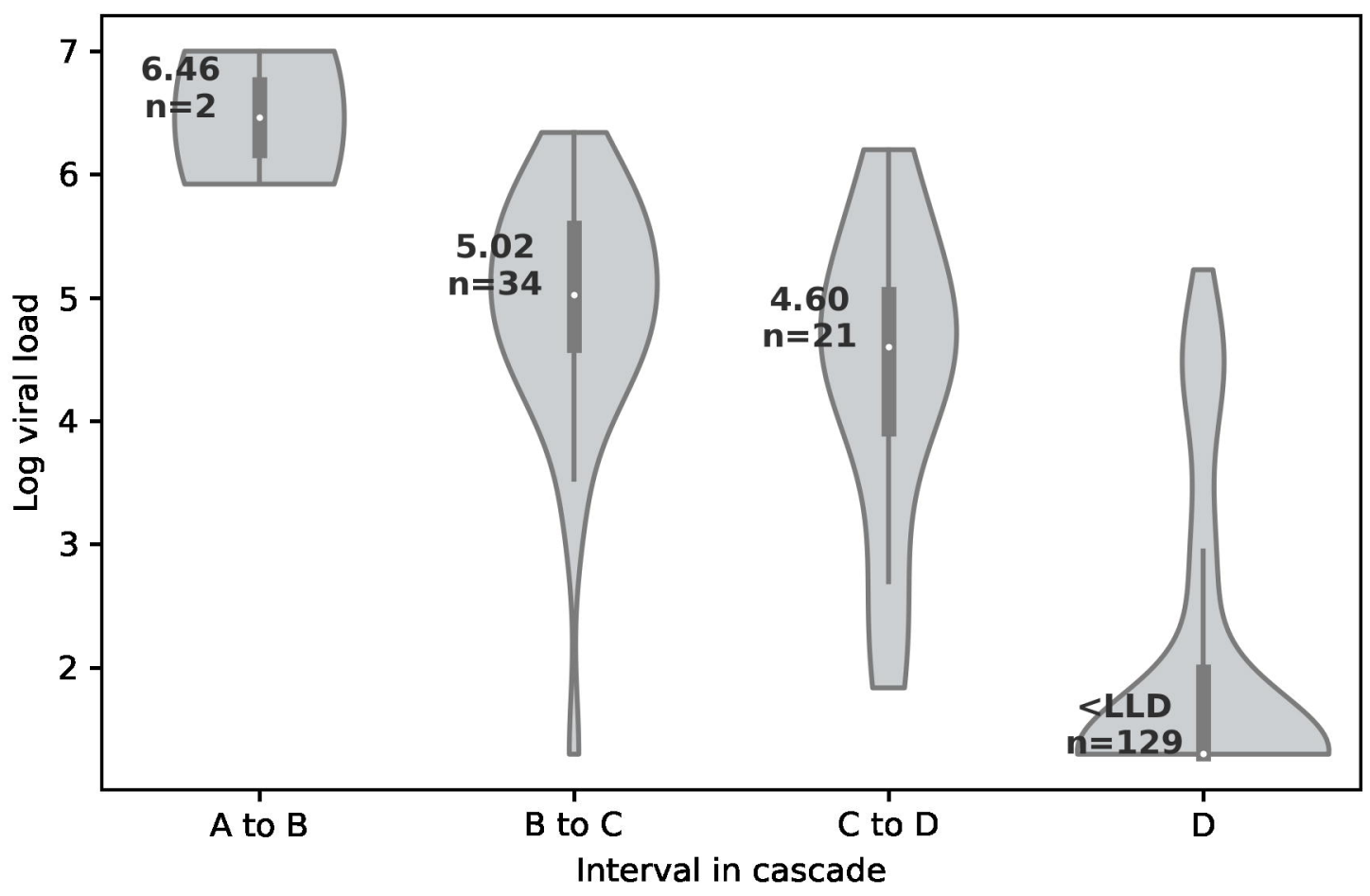




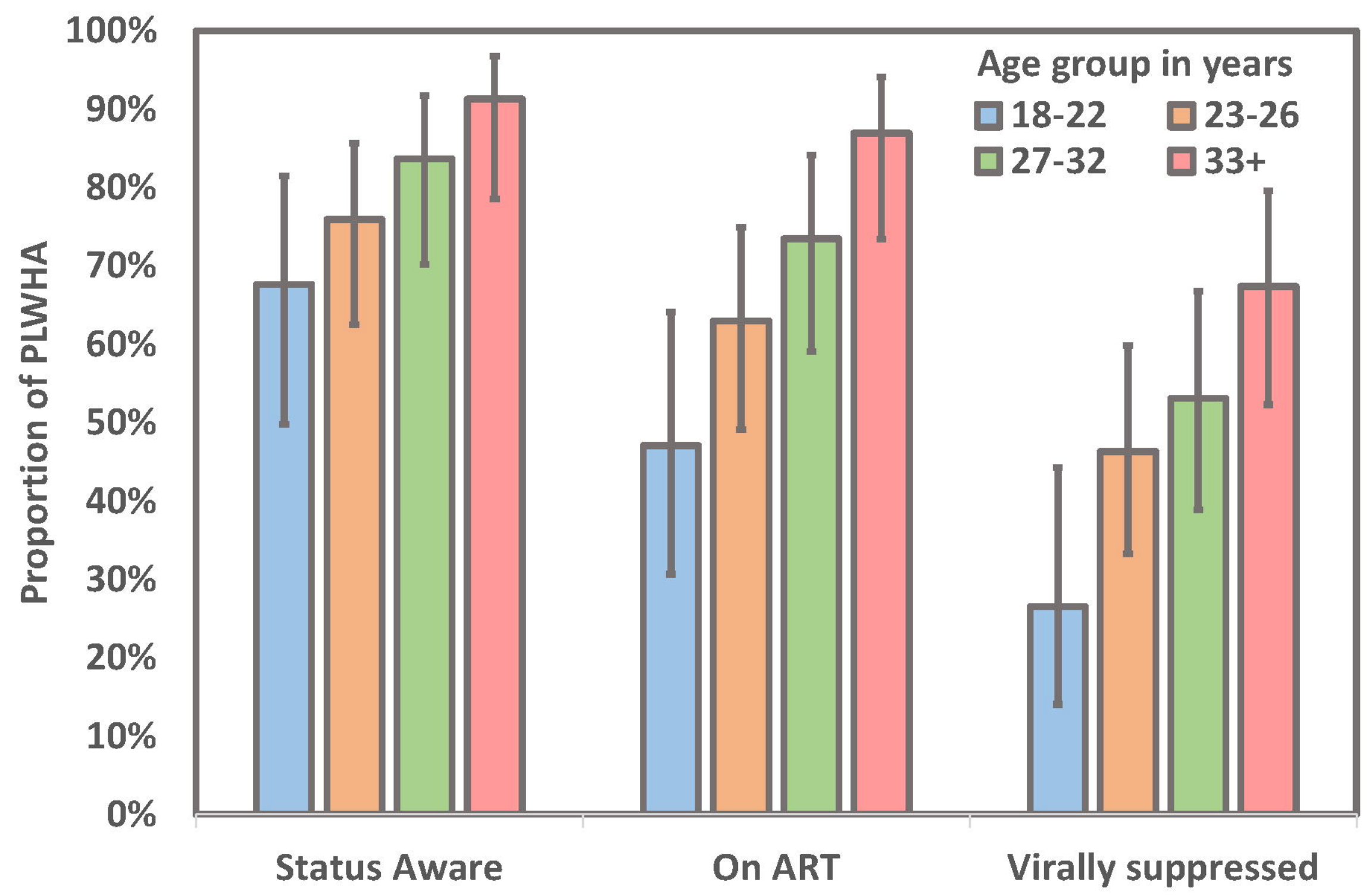




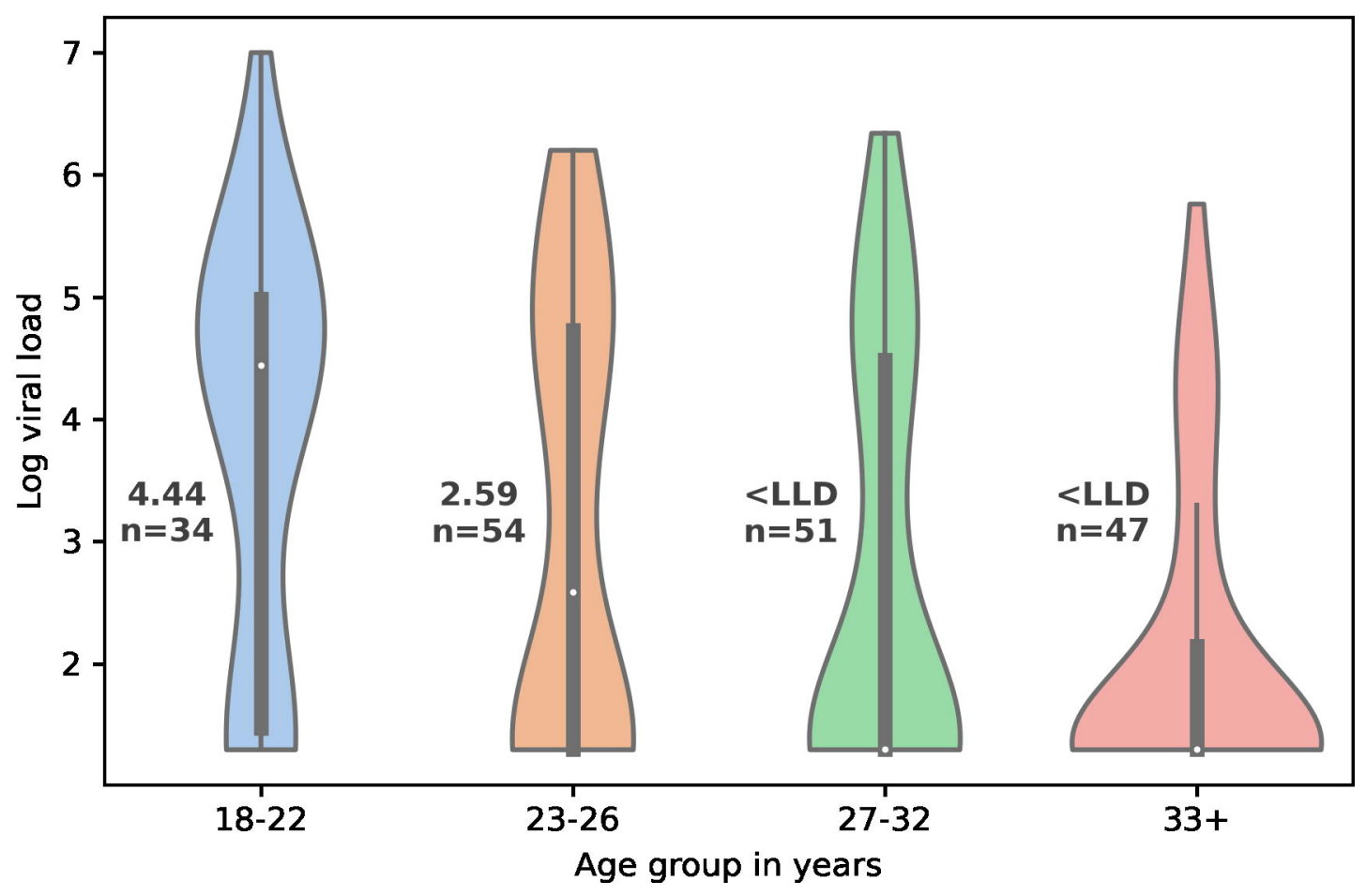

